Article

\title{
On the Synthesis and Characterization of Lanthanide Metal-Organic Frameworks
}

\author{
Andrius Laurikenas, Aldona Beganskiene and Aivaras Kareiva * \\ Department of Inorganic Chemistry, Institute of Chemistry, Vilnius University, Naugarduko 24, \\ LT-03225 Vilnius, Lithuania; andrius.lauriken@gmail.com (A.L.); aldona.beganskiene@chf.vu.lt (A.B.) \\ * Correspondence: aivaras.kareiva@chgf.vu.lt
}

Received: 28 March 2018; Accepted: 11 June 2018; Published: 12 June 2018

\begin{abstract}
In this study, lanthanide metal-organic frameworks $\mathrm{Ln}(\mathrm{BTC})(\mathrm{DMF})_{2}\left(\mathrm{H}_{2} \mathrm{O}\right)(\mathrm{LnMOFs})$ are synthesized using the metal nitrates as lanthanide $(\mathrm{Ln}=\mathrm{La}, \mathrm{Ce}, \mathrm{Pr}, \mathrm{Nd}, \mathrm{Sm}, \mathrm{Eu}, \mathrm{Tb}, \mathrm{Dy}, \mathrm{Ho}$, $\mathrm{Er}, \mathrm{Tm}, \mathrm{Yb}$ and $\mathrm{Lu}$ ) source and 1,3,5-benzenetricarboxylic acid (BTC) as a coordination ligand. X-ray diffraction (XRD) analysis, Fourier-transform infrared spectroscopy (FTIR), thermogravimetric (TG/DTG) analysis fluorescence spectroscopy (FLS), and scanning electron microscopy (SEM) are employed to characterize the newly synthesized LnMOFs.
\end{abstract}

Keywords: lanthanides; metal-organic framework; 1,3,5-benzentricarboxylic acid; synthesis; luminescence

\section{Introduction}

Metal-organic frameworks (MOFs), having zeolite-like network structure, are synthesized by self-assembly of polydentatic organic ligands and metal ions [1,2]. MOFs are characterized as materials having large surface area, highly porous structures, and large (tunable) pore volume. In today's world, MOF are used in aspects of gas storage, gas and liquid adsorption and separation, luminescence, catalysis, and in electrochemical biosensors for ultrasensitive detection [1-5].

The metal ion center has a key role for metal-organic frameworks. Lanthanides possess a unique electronic shell structure because their $4 \mathrm{f}$ electron shells are not completely filled, and the number of electrons in $4 \mathrm{f}$ shells varies, in this case, lanthanides have relatively high coordination numbers, which allows us to synthesize MOF with desired structures. The synthesis of lanthanide metal-organic framework is dependent on a variety of internal and external parameters, such as ionic radius, reaction temperature, atmosphere, coordinating solvents, and the nature of counter anions. Lanthanide metal-organic frameworks having high porosity, specific pore size, and 2D and 3D coordination networks could be used as heterogeneous catalysts in organic synthesis and solvent-free reactions $[3,4,6,7]$. General metal-organic framework synthesis types include solvothermal, hydrothermal, and solvent-free methods [8-11]. In this study, the solvothermal synthesis method was chosen, aiming for good crystallinity of synthesised MOFs [3,4].

In this work, the lanthanide metal-organic frameworks (LnMOFs) $\mathrm{Ln}(\mathrm{BTC})(\mathrm{DMF})_{2}\left(\mathrm{H}_{2} \mathrm{O}\right)(\mathrm{Ln}=\mathrm{La}$, $\mathrm{Ce}, \mathrm{Pr}, \mathrm{Nd}, \mathrm{Sm}, \mathrm{Eu}, \mathrm{Tb}, \mathrm{Dy}, \mathrm{Ho}, \mathrm{Er}, \mathrm{Tm}, \mathrm{Yb}$ and $\mathrm{Lu}$ ) were synthesized using the solvothermal method [1-4] at elevated temperature. The lanthanide nitrates and 1,3,5-benzenetricarboxylic acid (BTC) were used as a metal ion center and ligand, respectively.

\section{Experimental}

Lanthanide nitrates, 1,3,5-benzentricarboxylic acid (BTC), N,N-dimethylformamide, and methanol were purchased from Aldrich and used directly without further purification. The syntheses of MOFs were performed using the following procedures: 
$\mathrm{La}^{3+}(\mathbf{B T C})(\mathrm{DMF})_{2}\left(\mathrm{H}_{2} \mathrm{O}\right)$ (LaMOF). $\mathrm{La}\left(\mathrm{NO}_{3}\right)_{3} \cdot 6 \mathrm{H}_{2} \mathrm{O}(0.322 \mathrm{~g}, 0.75 \mathrm{mmol})$ was dissolved in $\mathrm{N}, \mathrm{N}$-dimethylformide/water $(3: 1 \mathrm{v} / \mathrm{v})$ mixture $(20 \mathrm{~mL}) .(0.116 \mathrm{~g}, 0.55 \mathrm{mmol}) \mathrm{BTC}$ was added and mixture was stirred for $30 \mathrm{~min}$ at room temperature. After complete dissolution the mixture was kept in the furnace at $65{ }^{\circ} \mathrm{C}$ for $24 \mathrm{~h}$. The formed transparent rod-like crystals were filtered on a dense paper filter, washed with methanol (15) $\mathrm{mL}$ three times. Crystals were punt into chloroform for solvent exchange (removal of DMF) for $24 \mathrm{~h}$, afterwards dried in air, which resulted in $0.195 \mathrm{~g}$ LaMOF, yield $45 \%$.

The preparation procedures for other lanthanide MOFs were analogous for LaMOF and were performed using different starting materials.

$\mathrm{Ce}^{3+}(\mathrm{BTC})(\mathrm{DMF})_{2}\left(\mathrm{H}_{2} \mathrm{O}\right) \quad(\mathrm{CeMOF})$. Using $\mathrm{Ce}\left(\mathrm{NO}_{3}\right)_{3} \cdot 6 \mathrm{H}_{2} \mathrm{O} \quad(0.324 \mathrm{~g}, 0.75 \mathrm{mmol})$ and $(0.116 \mathrm{~g}, 0.55 \mathrm{mmol})$ BTC. The synthesis yielded $0.231 \mathrm{~g}(51 \%)$ transparent rod-like $\mathrm{Ce}^{3+}(\mathrm{BTC})(\mathrm{DMF})_{2}\left(\mathrm{H}_{2} \mathrm{O}\right)$ crystals.

$\mathbf{P r}^{3+}(\mathrm{BTC})(\mathrm{DMF})_{2}\left(\mathrm{H}_{2} \mathrm{O}\right)$ (PrMOF). Using $\operatorname{Pr}\left(\mathrm{NO}_{3}\right)_{3} \cdot 6 \mathrm{H}_{2} \mathrm{O}(0.324 \mathrm{~g}, 0.75 \mathrm{mmol})$ and $(0.116 \mathrm{~g}, 0.55 \mathrm{mmol}) \mathrm{BTC}$. The synthesis yielded $0.177 \mathrm{~g}(40 \%)$ green transparent rod-like $\mathrm{Pr}^{3+}(\mathrm{BTC})(\mathrm{DMF})_{2}\left(\mathrm{H}_{2} \mathrm{O}\right)$ crystals.

$\mathbf{N d}^{3+}(\mathbf{B T C})(\mathbf{D M F})_{2}\left(\mathbf{H}_{\mathbf{2}} \mathrm{O}\right)(\mathbf{N d M O F})$. Using $\mathrm{Nd}\left(\mathrm{NO}_{3}\right)_{3} \cdot 6 \mathrm{H}_{2} \mathrm{O}(0.326 \mathrm{~g}, 0.75 \mathrm{mmol})$ and $(0.116 \mathrm{~g}$, $0.55 \mathrm{mmol}) \mathrm{BTC}$. The synthesis yielded $0.256 \mathrm{~g}(51 \%)$ slightly purple $\mathrm{Nd}^{3+}(\mathrm{BTC})(\mathrm{DMF})_{2}\left(\mathrm{H}_{2} \mathrm{O}\right)$ powder.

$\mathrm{Sm}^{3+}(\mathbf{B T C})(\mathbf{D M F})_{2}\left(\mathrm{H}_{2} \mathrm{O}\right) \quad$ (SmMOF). Using $\mathrm{Sm}\left(\mathrm{NO}_{3}\right)_{3} \cdot 4 \mathrm{H}_{2} \mathrm{O} \quad(0.331 \mathrm{~g}, \quad 0.75 \mathrm{mmol})$ and $(0.116 \mathrm{~g}, 0.55 \mathrm{mmol})$ BTC. The synthesis yielded $0.21 \mathrm{~g}(43 \%)$ yellowish rod-like $\mathrm{Sm}^{3+}(\mathrm{BTC})(\mathrm{DMF})_{2}\left(\mathrm{H}_{2} \mathrm{O}\right)$ crystals.

$\mathrm{Eu}^{3+}(\mathbf{B T C})(\mathrm{DMF})_{\mathbf{2}}\left(\mathrm{H}_{\mathbf{2}} \mathrm{O}\right)$ (EuMOF). Using $\mathrm{Eu}\left(\mathrm{NO}_{3}\right)_{3} \cdot 5 \mathrm{H}_{2} \mathrm{O}(0.332 \mathrm{~g}, 0.75 \mathrm{mmol})$ and $(0.116 \mathrm{~g}$, $0.55 \mathrm{mmol})$ BTC. The synthesis yielded $0.271 \mathrm{~g}(56 \%)$ white rod-like $\mathrm{Eu}^{3+}(\mathrm{BTC})(\mathrm{DMF})_{2}\left(\mathrm{H}_{2} \mathrm{O}\right)$ crystals.

$\left.\mathrm{Gd}^{3+}(\mathbf{B T C})(\mathbf{D M F})_{2} \mathbf{( H}_{\mathbf{2}} \mathrm{O}\right)$ (GdMOF). Using $\mathrm{Gd}\left(\mathrm{NO}_{3}\right)_{3} \cdot 6 \mathrm{H}_{2} \mathrm{O}(0.336 \mathrm{~g}, 0.75 \mathrm{mmol})$ and $(0.116 \mathrm{~g}$, $0.55 \mathrm{mmol}) \mathrm{BTC}$. The synthesis yielded $0.203 \mathrm{~g}(52 \%)$ white $\mathrm{Gd}^{3+}(\mathrm{BTC})(\mathrm{DMF})_{2}\left(\mathrm{H}_{2} \mathrm{O}\right)$ powder.

$\mathrm{Tb}^{3+}(\mathbf{B T C})(\mathrm{DMF})_{2}\left(\mathrm{H}_{2} \mathrm{O}\right) \quad$ (TbMOF). Using $\mathrm{Tb}\left(\mathrm{NO}_{3}\right)_{3} \cdot 5 \mathrm{H}_{2} \mathrm{O} \quad(0.337 \mathrm{~g}, \quad 0.75 \mathrm{mmol})$ and $(0.116 \mathrm{~g}, 0.55 \mathrm{mmol})$ BTC. The synthesis yielded $0.271 \mathrm{~g}(56 \%)$ colourless rod-like $\mathrm{Tb}^{3+}(\mathrm{BTC})(\mathrm{DMF})_{2}\left(\mathrm{H}_{2} \mathrm{O}\right)$ crystals.

$\mathrm{Dy}^{3+}(\mathbf{B T C})(\mathrm{DMF})_{2}\left(\mathrm{H}_{2} \mathrm{O}\right) \quad$ (DyMOF). Using $\quad \mathrm{Dy}\left(\mathrm{NO}_{3}\right)_{3} \cdot 6 \mathrm{H}_{2} \mathrm{O} \quad(0.340 \quad \mathrm{~g}, \quad 0.75 \mathrm{mmol})$ and $(0.116 \mathrm{~g}, 0.55 \mathrm{mmol}) \mathrm{BTC}$. The synthesis yielded $0.211 \mathrm{~g}(59 \%)$ yellowish rod-like $\mathrm{Dy}^{3+}(\mathrm{BTC})(\mathrm{DMF})_{2}\left(\mathrm{H}_{2} \mathrm{O}\right)$ crystals.

$\mathbf{H o}^{3+}(\mathbf{B T C})(\mathbf{D M F})_{2}\left(\mathrm{H}_{\mathbf{2}} \mathrm{O}\right)$ (HoMOF). Using $\mathrm{Ho}\left(\mathrm{NO}_{3}\right)_{3} \cdot 5 \mathrm{H}_{2} \mathrm{O}(0.342 \mathrm{~g}, 0.75 \mathrm{mmol})$ and $(0.116 \mathrm{~g}$, $0.55 \mathrm{mmol}) \mathrm{BTC}$. The synthesis yielded $0.251 \mathrm{~g}(49 \%)$ pink rod-like $\mathrm{Ho}^{3+}(\mathrm{BTC})(\mathrm{DMF})_{2}\left(\mathrm{H}_{2} \mathrm{O}\right)$ crystals.

$\mathrm{Er}^{3+}(\mathrm{BTC})(\mathrm{DMF})_{2}\left(\mathrm{H}_{2} \mathrm{O}\right)$ (ErMOF). Using $\mathrm{Er}\left(\mathrm{NO}_{3}\right)_{3} \cdot 6 \mathrm{H}_{2} \mathrm{O}(0.343 \mathrm{~g}, 0.75 \mathrm{mmol})$ and $(0.116 \mathrm{~g}$, $0.55 \mathrm{mmol}) \mathrm{BTC}$. The synthesis yielded $0.209 \mathrm{~g}(50 \%)$ pink rod-like $\mathrm{Er}^{3+}(\mathrm{BTC})(\mathrm{DMF})_{2}\left(\mathrm{H}_{2} \mathrm{O}\right)$ crystals.

$\mathrm{Tm}^{3+}(\mathbf{B T C})(\mathrm{DMF})_{2}\left(\mathrm{H}_{\mathbf{2}} \mathrm{O}\right)$ (TmMOF). Using $\mathrm{Tm}\left(\mathrm{NO}_{3}\right)_{3} \cdot 5 \mathrm{H}_{2} \mathrm{O}(0.345 \mathrm{~g}, 0.75 \mathrm{mmol})$ and $(0.116 \mathrm{~g}, 0.55 \mathrm{mmol})$ BTC. The synthesis yielded $0.148 \mathrm{~g}(36 \%)$ slightly green rod-like $\mathrm{Tm}^{3+}(\mathrm{BTC})(\mathrm{DMF})_{2}\left(\mathrm{H}_{2} \mathrm{O}\right)$ crystals.

$\mathbf{Y b}^{3+}(\mathbf{B T C})(\mathrm{DMF})_{2}\left(\mathrm{H}_{2} \mathrm{O}\right) \quad(\mathrm{YbMOF})$. Using $\mathrm{Yb}\left(\mathrm{NO}_{3}\right)_{3} \cdot 6 \mathrm{H}_{2} \mathrm{O}(0.348 \mathrm{~g}, 0.75 \mathrm{mmol})$ and $(0.116 \mathrm{~g}, 0.55 \mathrm{mmol})$ BTC. The synthesis yielded $0.199 \mathrm{~g}(41 \%)$ slightly green rod-like $\mathrm{Yb}^{3+}(\mathrm{BTC})(\mathrm{DMF})_{2}\left(\mathrm{H}_{2} \mathrm{O}\right)$ crystals.

$\mathrm{Lu}^{3+}(\mathrm{BTC})(\mathrm{DMF})_{\mathbf{2}}\left(\mathrm{H}_{2} \mathrm{O}\right)$ (LuMOF). Using $\mathrm{Lu}\left(\mathrm{NO}_{3}\right)_{3} \cdot 6 \mathrm{H}_{2} \mathrm{O}(0.349 \mathrm{~g}, 0.75 \mathrm{mmol})$ and $(0.116 \mathrm{~g}, 0.55 \mathrm{mmol}) \mathrm{BTC}$. The synthesis yielded $0.192 \mathrm{~g}(45 \%)$ slightly green rod-like $\mathrm{Lu}^{3+}(\mathrm{BTC})(\mathrm{DMF})_{2}\left(\mathrm{H}_{2} \mathrm{O}\right)$ crystals.

XRD data were collected at room temperature on a Rigaku Miniflex II system with a graphite monochromator, using $\mathrm{Cu} \mathrm{K} \alpha 1$ radiation (speed $1^{\circ} / \mathrm{min}$ ). FTIR analysis of compounds was conducted using a Bruker Alpha FTIR spectrometer with Platinum ATR single reflection diamond module. Thermal analyses were conducted from room temperature to $600^{\circ} \mathrm{C}$ under air atmosphere using Perkin Elmer Pyris 1 TGA thermal analyser and Pyris software. The heating rate was $5{ }^{\circ} \mathrm{C} / \mathrm{min}$. Excitation and emission measurements were acquired using Edinburgh Instruments FLS980 fluorescence spectrometer. 
The emission spectra were conducted in the solid state. Scanning electron microscope (SEM) Hitachi TM3000 was used to study the main morphological features of obtained crystals.

\section{Results and Discussion}

\subsection{XRD Analysis}

The synthesised fourteen lanthanide metal-organic frameworks were found to be isomorphous having very similar structures. However, only the structure of LaMOF is described here in detail (Figure 1).

LaMOF is a three-dimensional open framework. Each asymmetric unit contains one eight-coordinated $\mathrm{La}^{3+}$ ion, one BTC ligand, two coordinated DMF molecules, with eight oxygen atoms from four BTC ligands through two chelating carboxylate groups (O1-O4), two carboxylate groups (O5 and O6), and two terminal DMF molecules (O7 and O8). In the LaMOF molecule, one $\mathrm{La}^{3+}$ ion is linked with four phenyl groups through two chelating bidentate carboxylate groups and two monodentate carboxylate groups.

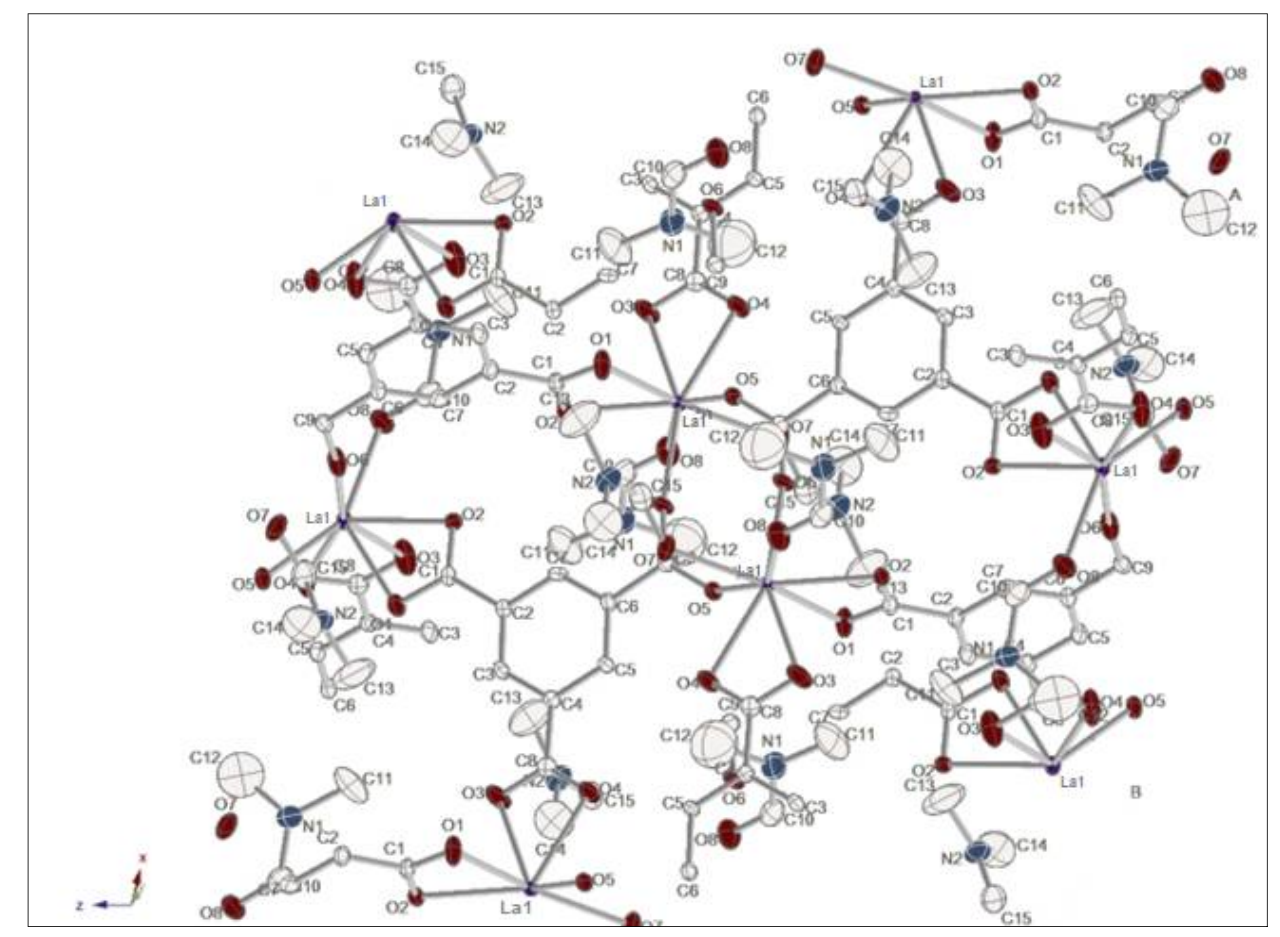

Figure 1. Coordination environment of $\mathrm{La}(\mathrm{BTC})(\mathrm{DMF})_{2}\left(\mathrm{H}_{2} \mathrm{O}\right)(\mathrm{LaMOF})$ with atoms represented by thermal ellipsoids ( $40 \%$ probability level). The hydrogen atoms are omitted.

The XRD patterns LnMOFs are presented in Figure 2. As seen, the XRD patterns of $\mathrm{Ln}(\mathrm{BTC})(\mathrm{DMF})_{2}\left(\mathrm{H}_{2} \mathrm{O}\right)(\mathrm{Ln}=\mathrm{La}, \mathrm{Ce}, \mathrm{Eu}, \mathrm{Gd}, \mathrm{Tb}, \mathrm{Dy}, \mathrm{Ho}, \mathrm{Tm}, \mathrm{Yb}$ and $\mathrm{Lu})$ show good agreement with standard ICDD PDF patterns. The comparison of experimental and standard data demonstrates the formation of monophasic compounds under the applied synthesis conditions. Moreover, these MOFs were prepared with very well-developed crystalline structure. The XRD patterns of $\mathrm{Ln}(\mathrm{BTC})(\mathrm{DMF})_{2}\left(\mathrm{H}_{2} \mathrm{O}\right)(\mathrm{Ln}=\mathrm{Er}, \mathrm{Pr}, \mathrm{Nd}$ and $\mathrm{Sm})$ displayed lower crystallinity of synthesized compounds. (Figure 2) The crystallographic data of fabricated LnMOFs are summarized in Table 1. 
Table 1. Crystallographic data of LnMOFs.

\begin{tabular}{|c|c|c|c|c|c|c|c|}
\hline & LaMOF & CeMOF & PrMOF & NdMOF & SmMOF & EuMOF & GdMOF \\
\hline Empirical Formula & $\mathrm{C}_{15} \mathrm{H}_{19} \mathrm{~N}_{2} \mathrm{O}_{9} \mathrm{La}$ & $\mathrm{C}_{15} \mathrm{H}_{19} \mathrm{~N}_{2} \mathrm{O}_{9} \mathrm{Ce}$ & $\mathrm{C}_{15} \mathrm{H}_{19} \mathrm{~N}_{2} \mathrm{O}_{9} \mathrm{Pr}$ & $\mathrm{C}_{15} \mathrm{H}_{19} \mathrm{~N}_{2} \mathrm{O}_{9} \mathrm{Nd}$ & $\mathrm{C}_{15} \mathrm{H}_{19} \mathrm{~N}_{2} \mathrm{O}_{9} \mathrm{Sm}$ & $\mathrm{C}_{15} \mathrm{H}_{19} \mathrm{~N}_{2} \mathrm{O}_{9} \mathrm{Eu}$ & $\mathrm{C}_{15} \mathrm{H}_{19} \mathrm{~N}_{2} \mathrm{O}_{9} \mathrm{Gd}$ \\
\hline Formula Weight & 509.9 & 511.12 & 511.91 & 515.24 & 521.36 & 522.96 & 528.25 \\
\hline Crystal System & monoclinic & monoclinic & monoclinic & monoclinic & monoclinic & monoclinic & monoclinic \\
\hline Space Group & $\mathrm{C} 2 / \mathrm{c}$ & $\mathrm{C} 2 / \mathrm{c}$ & $\mathrm{C} 2 / \mathrm{c}$ & $\mathrm{C} 2 / \mathrm{c}$ & $\mathrm{C} 2 / \mathrm{c}$ & $\mathrm{C} 2 / \mathrm{c}$ & $\mathrm{C} 2 / \mathrm{c}$ \\
\hline a $(\AA)$ & 18.896 & 18.847 & 18.798 & 18.749 & 18.7 & 18.651 & 18.602 \\
\hline $\mathrm{b}(\AA)$ & 11.649 & 11.682 & 11.673 & 11.601 & 11.615 & 11.66 & 11.59 \\
\hline$c(\AA)$ & 19.866 & 19.906 & 19.851 & 19.897 & 19.849 & 19.795 & 19.688 \\
\hline$\beta$ (deg) & 75.447 & 72.783 & 73.13 & 74.4 & 72.97 & 73.11 & 72.9 \\
\hline$V\left(\AA^{3}\right)$ & 4232.6 & 4186.34 & 4168.43 & 4129.64 & 4122.17 & 4119.14 & 4057.03 \\
\hline \multirow[t]{2}{*}{ Z } & 8 & 8 & 8 & 8 & 8 & 8 & 8 \\
\hline & TbMOF & DyMOF & HoMOF & ErMOF & TmMOF & YbMOF & LuMOF \\
\hline Empirical Formula & $\mathrm{C}_{15} \mathrm{H}_{19} \mathrm{~N}_{2} \mathrm{O}_{9} \mathrm{~Tb}$ & $\mathrm{C}_{15} \mathrm{H}_{19} \mathrm{~N}_{2} \mathrm{O}_{9} \mathrm{Dy}$ & $\mathrm{C}_{15} \mathrm{H}_{19} \mathrm{~N}_{2} \mathrm{O}_{9} \mathrm{Ho}$ & $\mathrm{C}_{15} \mathrm{H}_{19} \mathrm{~N}_{2} \mathrm{O}_{9} \mathrm{Er}$ & $\mathrm{C}_{15} \mathrm{H}_{19} \mathrm{~N}_{2} \mathrm{O}_{9} \mathrm{Tm}$ & $\mathrm{C}_{15} \mathrm{H}_{19} \mathrm{~N}_{2} \mathrm{O}_{9} \mathrm{Yb}$ & $\mathrm{C}_{15} \mathrm{H}_{19} \mathrm{~N}_{2} \mathrm{O}_{9} \mathrm{Lu}$ \\
\hline Formula Weight & 530.24 & 533.82 & 536.25 & 538.58 & 540.25 & 544.36 & 545.96 \\
\hline Crystal System & monoclinic & monoclinic & monoclinic & monoclinic & monoclinic & monoclinic & monoclinic \\
\hline Space Group & $\mathrm{C} 2 / \mathrm{c}$ & $\mathrm{C} 2 / \mathrm{c}$ & $\mathrm{C} 2 / \mathrm{c}$ & $\mathrm{C} 2 / \mathrm{c}$ & $\mathrm{C} 2 / \mathrm{c}$ & $\mathrm{C} 2 / \mathrm{c}$ & $\mathrm{C} 2 / \mathrm{c}$ \\
\hline $\mathrm{a}(\AA)$ & 18.568 & 18.493 & 18.44 & 18.401 & 18.382 & 18.299 & 18.258 \\
\hline $\mathrm{b}(\AA)$ & 11.63 & 11.58 & 11.647 & 11.649 & 11.592 & 11.592 & 11.578 \\
\hline$c(\AA)$ & 19.741 & 19.51 & 19.698 & 19.68 & 19.632 & 19.557 & 19.592 \\
\hline$\beta$ (deg) & 72. 97 & 72.79 & 72.945 & 73.03 & 72.92 & 72.98 & 72.58 \\
\hline$V\left(\AA^{3}\right)$ & 4072.3 & 3991 & 4044.5 & 4034.8 & 3998.8 & 3966.9 & 3951.62 \\
\hline $\mathrm{Z}$ & 8 & 8 & 8 & 8 & 8 & 8 & 8 \\
\hline
\end{tabular}



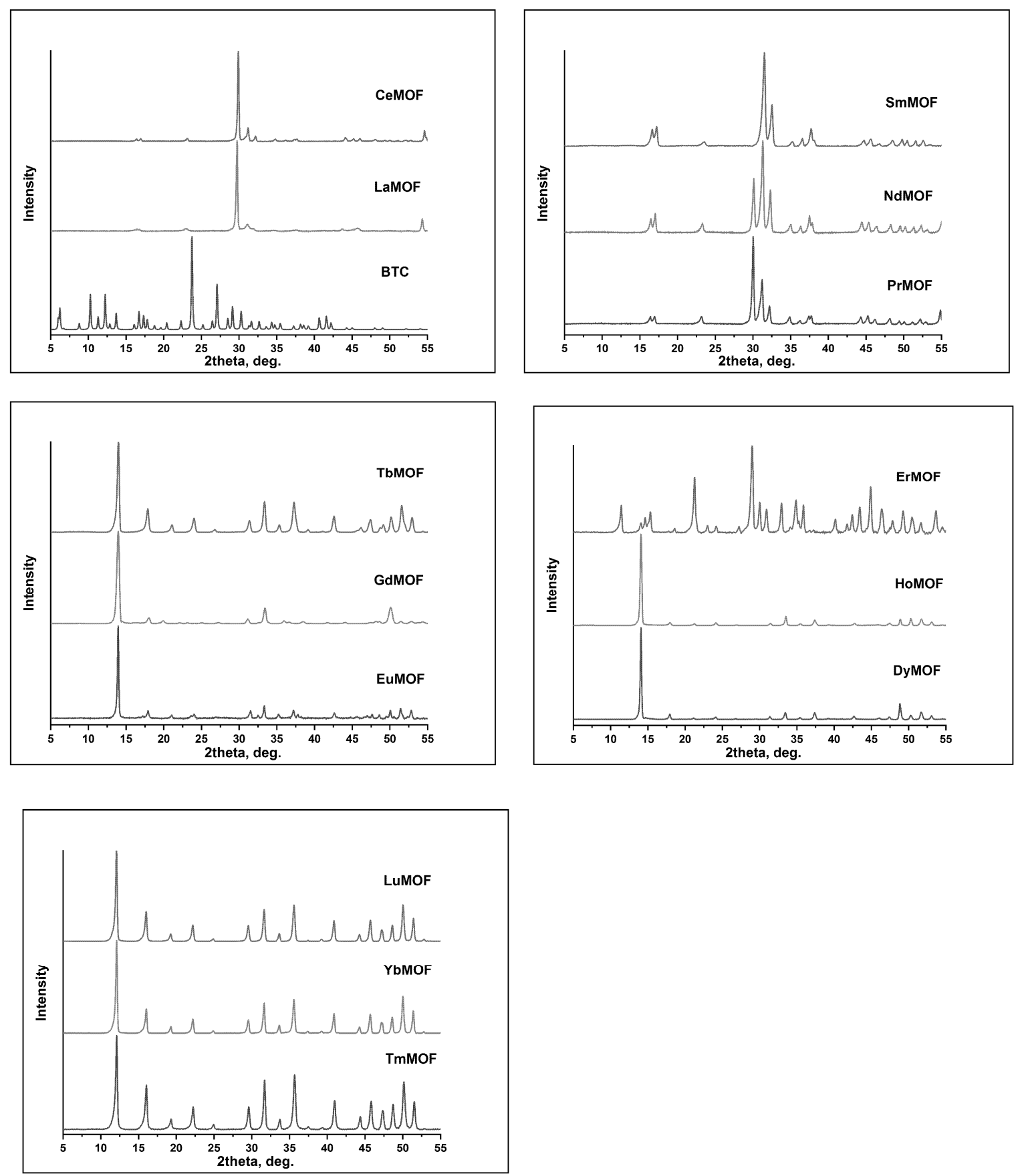

Figure 2. XRD patterns of synthesised lanthanide $(\mathrm{Ln}=\mathrm{La}-\mathrm{Lu})$ metal-organic frameworks.

\subsection{Infrared (FTIR) Spectroscopy}

All the FTIR spectra of synthesized lanthanide metal-organic frameworks were very similar (see Figure 3). Asymmetric and symmetric stretching vibrations of the BTC ligand carboxylate groups displayed bands at 1556 and $1382 \mathrm{~cm}^{-1}$. The bands at 1621,3078,689, and $780 \mathrm{~cm}^{-1}$ are assigned to the vibration of aromatic skeleton of the benzene ring [12]. The bands at 1678 and $2915 \mathrm{~cm}^{-1}$ are assigned to $v \mathrm{CO}$ and the asymmetric stretching vibration of the $-\mathrm{CH}_{3}$ group of the $N, N$-dimethylformamide molecules [12,13]. The absence of FTIR bands at 2658, $2544(\mathrm{OCOOH})$, and $1691(\mathrm{CCOOH}) \mathrm{cm}^{-1}$ indicates that the BTC ligands were completely deprotonated after the reaction. The broad band at $3420 \mathrm{~cm}^{-1}$ is attributed to the hydrogen-bonded $v \mathrm{OH}$ groups from adsorbed (residual) water (Table 2). 


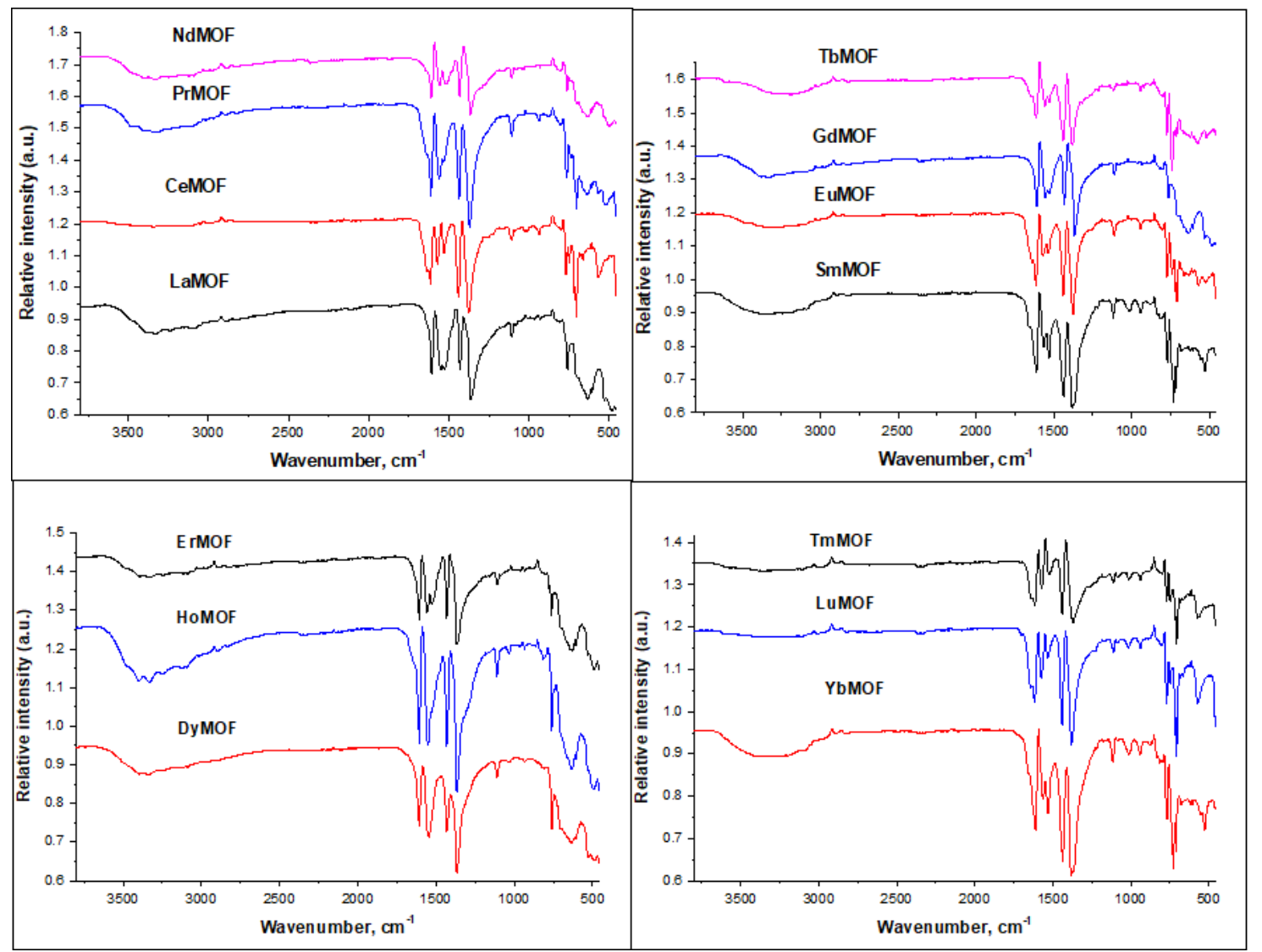

Figure 3. FTIR spectra of LnMOFs.

Table 2. FTIR assignments of synthesised LnMOFs.

\begin{tabular}{|c|c|c|c|c|c|c|}
\hline $\begin{array}{c}\text { Band } \\
\text { Wavenumber, } \mathrm{cm}^{-1}\end{array}$ & 689 and 780 & 1382 & 1556 & 1678 & 2915 & 3420 \\
\hline Assignment & $\begin{array}{l}\text { Vibrations of } \\
\text { 1,4-substituted } \\
\text { benzene ring }\end{array}$ & $\begin{array}{c}\text { Sym. stretching of } \\
\text { BTC carboxylic } \\
\text { groups }\end{array}$ & $\begin{array}{c}\text { Assym. stretching } \\
\text { of BTC carboxylic } \\
\text { groups }\end{array}$ & $\begin{array}{c}v(=\mathrm{CO}) \text { of } \\
\text { DMF }\end{array}$ & $\begin{array}{c}\text { Assym. } \\
\text { Stretch. of } \\
-\mathrm{CH}_{3} \text { in DMF }\end{array}$ & $\begin{array}{c}v(-\mathrm{OH}) \text { of } \\
\text { absorbed, } \\
\text { residual } \\
\text { water }\end{array}$ \\
\hline
\end{tabular}

\subsection{Thermal (TG/DTG) Analysis}

The TG/DTG curves of synthesized lanthanide-containing MOFs are shown in Figure 4.

As seen, all the MOF samples had similar thermal stability [14,15]. The first mass loss in DTG curves was observed at about $120^{\circ} \mathrm{C}$ (except for CeMOFs at $\sim 200{ }^{\circ} \mathrm{C}$ ). This first weight loss in the temperature range of $20-160^{\circ} \mathrm{C}$ corresponds to the loss of water molecules and adsorbed moisture. The main mass loss, which continuously occurred up to $400-450{ }^{\circ} \mathrm{C}$, is assigned to the decomposition of DMF. At higher temperatures (above $450{ }^{\circ} \mathrm{C}$ ) the mass loss is associated with final decomposition of MOFs and formation of $\mathrm{Ln}_{2} \mathrm{O}_{2} \mathrm{CO}_{3}$, or $\mathrm{Ln}_{2}\left(\mathrm{CO}_{3}\right)_{3}$ and $\mathrm{Ln}_{2} \mathrm{O}_{3}$ [16-18]. 

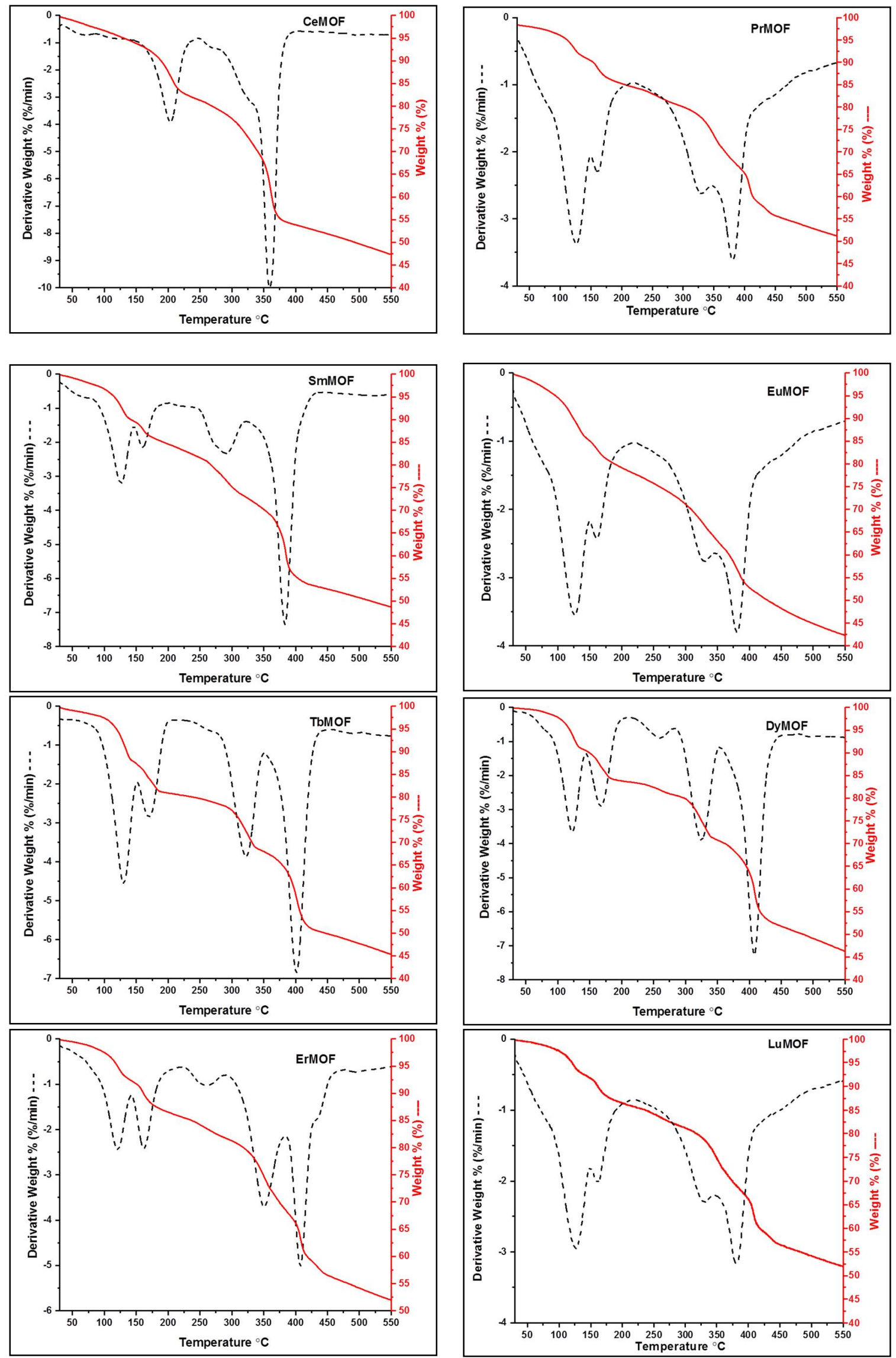

Figure 4. TG and DTG curves of synthesised lanthanide-containing MOFs. 


\subsection{Luminescent Properties}

It is well-known that lanthanides, especially Eu and $\mathrm{Tb}$, can absorb ultraviolet radiation efficiently through an allowed electronic transition to convert to excited state ${ }^{5} \mathrm{D}_{4}$, and these excited states are deactivated to the multiplet ${ }^{7} \mathrm{~F}_{\mathrm{J}}$ states by emitting visible light. Emission spectra of $\mathrm{Pr}, \mathrm{Sm}, \mathrm{Eu}$, and $\mathrm{Tb}$ metal-organic frameworks are shown in Figure 5. The intensity of emission lines situated at 325, 416, and $443 \mathrm{~nm}$ (UV-blue region) of $\operatorname{PrMOF}\left(\lambda_{\mathrm{ex}}=290 \mathrm{~nm}\right)$ were very weak.

The emission lines for SmMOF $\left(\lambda_{\mathrm{ex}}=275 \mathrm{~nm}\right)$ are assigned to ${ }^{4} \mathrm{G}_{5 / 2} \rightarrow{ }^{6} \mathrm{H}_{5 / 2},{ }^{4} \mathrm{G}_{5 / 2} \rightarrow{ }^{6} \mathrm{H}_{7 / 2}$, ${ }^{4} \mathrm{G}_{5 / 2} \rightarrow{ }^{6} \mathrm{H}_{9 / 2}$, and ${ }^{4} \mathrm{G}_{5 / 2} \rightarrow{ }^{6} \mathrm{H}_{11 / 2}$ transitions at 563, 601, 649 and $702 \mathrm{~nm}$ (yellow—orange region). The emission lines of synthesized EuMOF $\left(\lambda_{\mathrm{ex}}=285 \mathrm{~nm}\right)$ are assigned to ${ }^{5} \mathrm{D}_{0} \rightarrow{ }^{7} \mathrm{~F}_{0},{ }^{5} \mathrm{D}_{0} \rightarrow{ }^{7} \mathrm{~F}_{1}$, ${ }^{5} \mathrm{D}_{0} \rightarrow{ }^{7} \mathrm{~F}_{2},{ }^{5} \mathrm{D}_{0} \rightarrow{ }^{7} \mathrm{~F}_{3}$, and ${ }^{5} \mathrm{D}_{0} \rightarrow{ }^{7} \mathrm{~F}_{4}$ transitions at $579,593,613,618$, and $699 \mathrm{~nm}$, respectively (orange-red region). It can be observed that a very intense ${ }^{5} \mathrm{D}_{0} \rightarrow{ }^{7} \mathrm{~F}_{2}$ transition at $613 \mathrm{~nm}$ in the emission spectrum was dominating. It is known that the ${ }^{5} \mathrm{D}_{0} \rightarrow{ }^{7} \mathrm{~F}_{2}$ transition is an electric dipole transition and is very sensitive to the local symmetry of europium ions. For the TbMOF $\left(\lambda_{\mathrm{ex}}=285 \mathrm{~nm}\right)$ the emission lines are assigned to ${ }^{5} \mathrm{D}_{4} \rightarrow{ }^{7} \mathrm{~F}_{6},{ }^{5} \mathrm{D}_{4} \rightarrow{ }^{7} \mathrm{~F}_{5},{ }^{5} \mathrm{D}_{4} \rightarrow{ }^{7} \mathrm{~F}_{4},{ }^{5} \mathrm{D}_{4} \rightarrow{ }^{7} \mathrm{~F}_{3},{ }^{5} \mathrm{D}_{4} \rightarrow{ }^{7} \mathrm{~F}_{2},{ }^{5} \mathrm{D}_{4} \rightarrow{ }^{7} \mathrm{~F}_{0}$ transitions at 488,542,582, 620,646, and $679 \mathrm{~nm}$, respectively (blue green-green region). Very intense ${ }^{5} \mathrm{D}_{4} \rightarrow{ }^{7} \mathrm{~F}_{5}$ transition at $542 \mathrm{~nm}$ is observed in the emission spectrum of TbMOF.

The photoluminescence measurements showed that Ce and La MOFs with BTC ligands are optically inactive. This is in a good agreement with the literature data $[16,17]$. The synthesized $\mathrm{Nd}, \mathrm{Gd}$, $\mathrm{Dy}, \mathrm{Ho}, \mathrm{Er}, \mathrm{Tm}, \mathrm{Yb}$, Lu metal-organic frameworks, however, displayed very weak or even undetectable fluorescence at excitation wavelengths of $250-400 \mathrm{~nm}$.

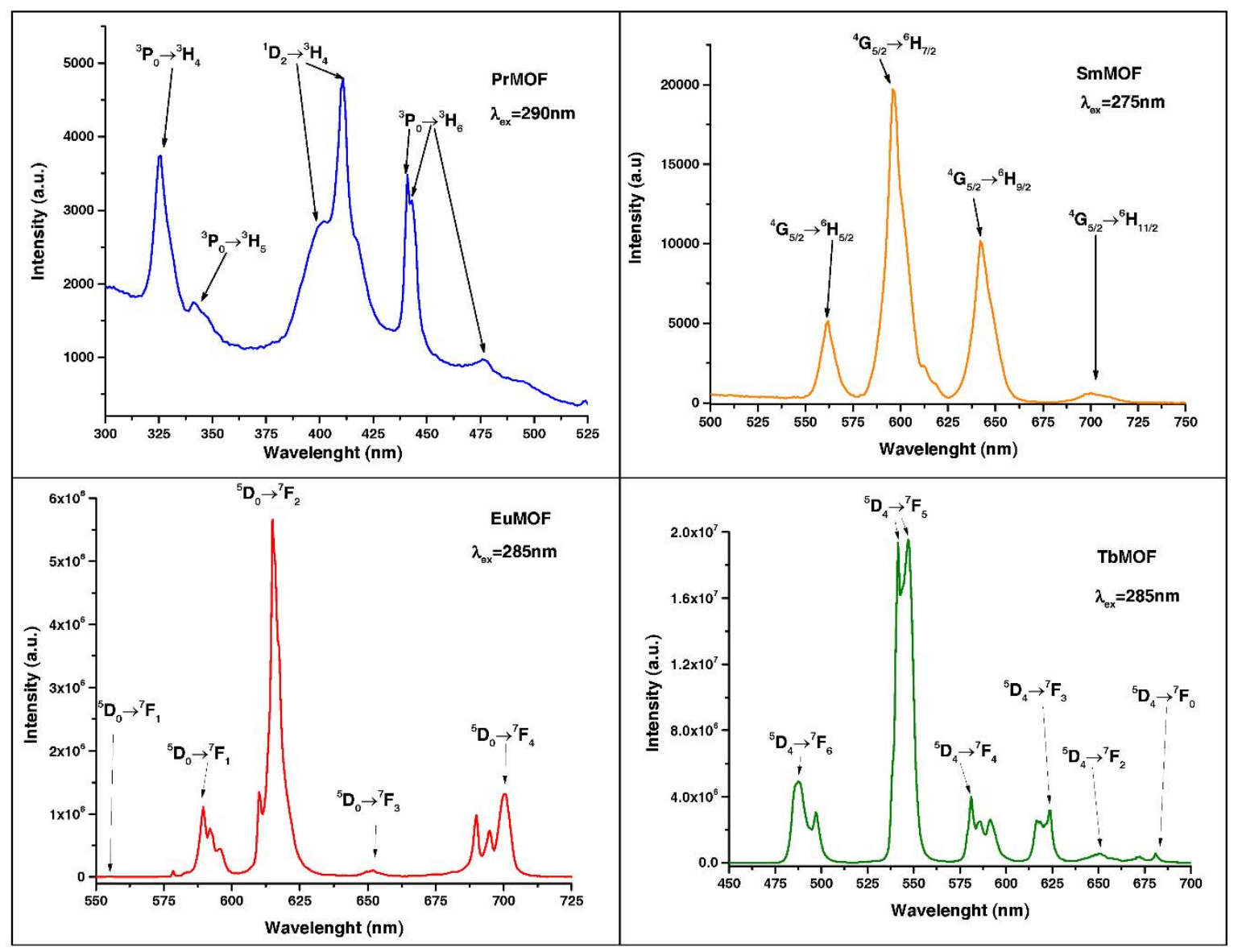

Figure 5. Emission spectra of $\mathrm{Pr}, \mathrm{Sm}, \mathrm{Eu}$ and $\mathrm{Tb}$ metal-organic frameworks. 


\subsection{Scanning Electron Microscopy}

The representative SEM micrographs of synthesized lanthanide MOFs are shown in Figure 6.
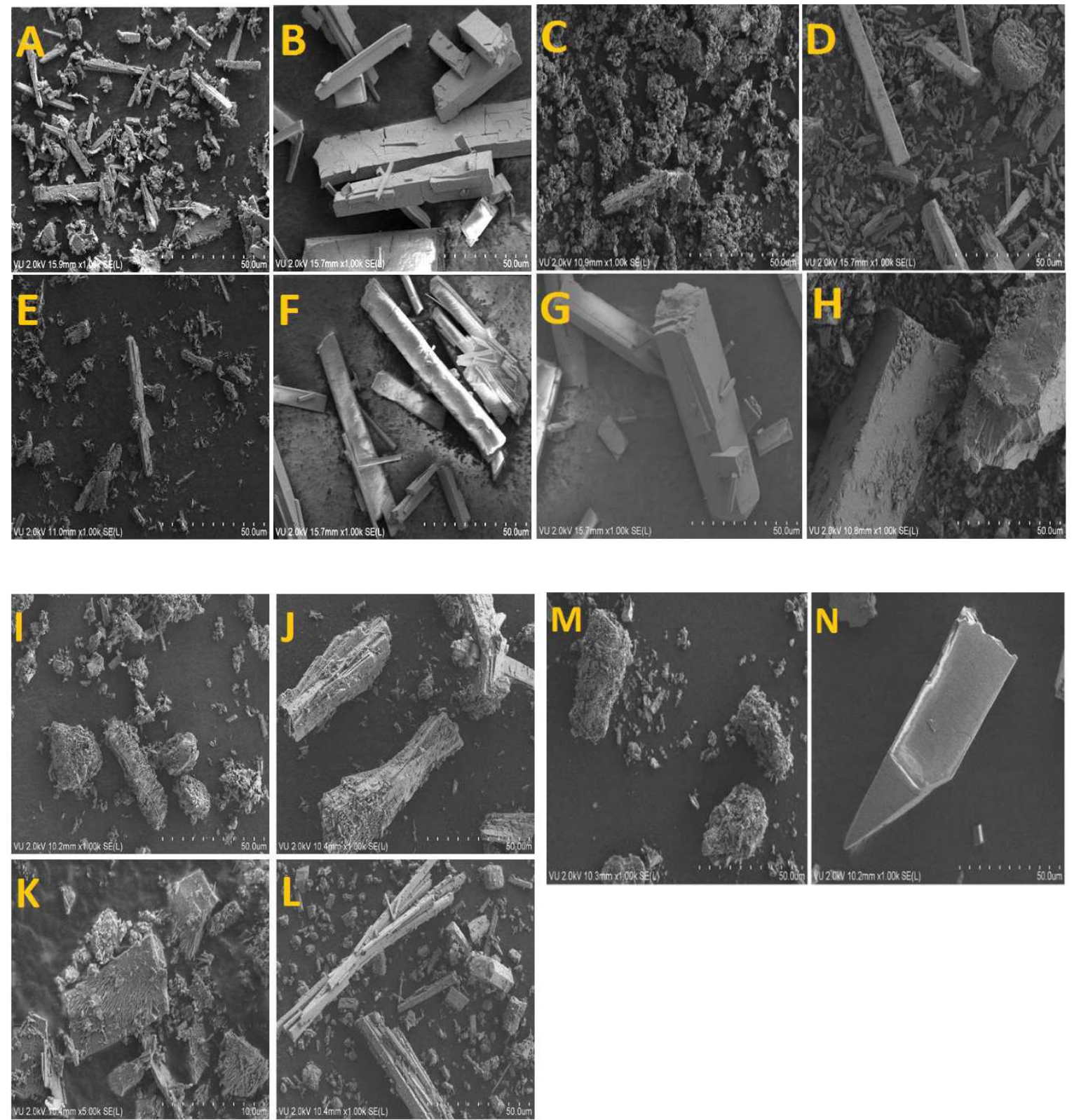

Figure 6. SEM images of synthesised metal-organic frameworks: $\mathrm{Ce}(\mathbf{A}), \operatorname{Pr}(\mathbf{B}), \mathrm{Nd}(\mathbf{C}), \mathrm{Sm}(\mathbf{D}), \mathrm{Tb}(\mathbf{E})$, $\mathrm{Eu}(\mathbf{F}), \operatorname{Er}(\mathbf{G}), \operatorname{Ho}(\mathbf{H}), \operatorname{Tm}(\mathbf{I}), \mathrm{La}(\mathbf{J}), \mathrm{Gd}(\mathbf{K}), \operatorname{Dy}(\mathbf{L}), \mathrm{Yb}(\mathbf{M}), \mathrm{Lu}(\mathbf{N})$.

The SEM results revealed that all compounds consist of two types of particles. In most of the cases the formed rectangular plate-like crystallites of 25-70 $\mu \mathrm{m}$ in size were covered with nanosized differently shaped particles. We can conclude that nature of lanthanide does not influence significantly the surface morphology of fabricated lanthanide MOFs.

\section{Conclusions}

The lanthanide metal-organic frameworks $\mathrm{Ln}(\mathrm{BTC})(\mathrm{DMF})_{2}\left(\mathrm{H}_{2} \mathrm{O}\right)(\mathrm{LnMOFs})(\mathrm{Ln}=\mathrm{La}, \mathrm{Ce}, \mathrm{Pr}, \mathrm{Nd}$, $\mathrm{Sm}, \mathrm{Eu}, \mathrm{Tb}, \mathrm{Dy}, \mathrm{Ho}, \mathrm{Er}, \mathrm{Tm}, \mathrm{Yb}$ and $\mathrm{Lu}$ ) were successfully synthesized using 1,3,5-benzenetricarboxylic acid (BTC) as a coordination ligand. These MOFs were obtained with very well-developed crystalline 
structure. All FTIR spectra of LnMOFs showed characteristic asymmetric and symmetric stretching vibration bands of the BTC ligand. The emission spectra of $\mathrm{Pr}, \mathrm{Sm}, \mathrm{Eu}$, and $\mathrm{Tb}$ metal-organic frameworks were discussed in this study, however, the $\mathrm{La}, \mathrm{Ce}, \mathrm{Nd}, \mathrm{Gd}, \mathrm{Dy}, \mathrm{Ho}, \mathrm{Er}, \mathrm{Tm}, \mathrm{Yb}$, and Lu metal-organic frameworks displayed very weak or even undetectable fluorescence at excitation wavelengths of 250-400 nm. The SEM micrographs of synthesized lanthanide MOFs showed the formation rectangular plate-like crystallites of $25-70 \mu \mathrm{m}$ in size covered with nanosized differently shaped particles.

Author Contributions: Conceptualization, A.K. and A.L.; Methodology, A.B.; Software, A.L.; Validation, A.L., A.B. and A.K.; Formal Analysis, A.B.; Investigation, A.L.; Resources, A.K.; Data Curation, A.L., A.B. and A.K.; Writing-Original Draft Preparation, A.L.; Writing-Review \& Editing, A.K.; Visualization, A.K.; Supervision, A.K.; Project Administration, A.B.; Funding Acquisition, A.K.

Funding: This research was funded by a grant SINALAN (No. S-LU-18-13) from the Research Council of Lithuania.

Conflicts of Interest: The authors declare no conflict of interest.

\section{References}

1. Guo, X.D.; Zhu, G.S.; Fang, Q.R.; Xue, M.; Tian, G.; Sun, J.Y.; Li, X.T.; Qiu, S.L. Synthesis, Structure and Luminescent Properties of Rare Earth Coordination Polymers Constructed from Paddle-Wheel Building Blocks. Inorg. Chem. 2005, 44, 3850-3855. [CrossRef] [PubMed]

2. Wang, L.H.; Li, P.F. Synthesis, Structure, and Catalytic Activity of A New Mn(II) Complex with 1,4-Phenylenediacetic Acid and 1,10-Phenanthroline. Bull. Chem. React. Eng. Catal. 2018, 13, 1-6. [CrossRef]

3. Rosi, N.L.; Kim, J.; Eddaoudi, M.; Chen, B.L.; O'Keeffe, M.; Yaghi, O.M. Rod Packings and Metal-Organic Frameworks Constructed from Rod-Shaped Secondary Building Units. J. Am. Chem. Soc. 2005, 127, 1504-1518. [CrossRef] [PubMed]

4. Laurikenas, A.; Katelnikovas, A.; Skaudzius, R.; Kareiva, A. Synthesis and characterization of Tb3+ and Eu ${ }^{3+}$ metal-organic frameworks with TFBDC ${ }^{2-}$ linkers. Opt. Mater. 2018, in press.

5. Li, Y.L.; Yu, C.; Yang, B.; Liu, Z.R.; Xia, P.Y.; Wang, Q. Target-catalyzed hairpin assembly and metal-organic frameworks mediated nonenzymatic co-reaction for multiple signal amplification detection of miR-122 in human serum. Biosens. Bioelctron. 2018, 102, 307-315. [CrossRef] [PubMed]

6. Li, X.Y.; Zhang, J.L.; Han, Y.; Zhu, M.Y.; Shang, S.S.; Li, W. MOF-derived various morphologies of N-doped carbon composites for acetylene hydrochlorination. J. Mater. Sci. 2018, 53, 4913-4926. [CrossRef]

7. Liu, X.M.; Tang, B.; Long, J.L.; Zhang, W.; Liu, X.H.; Mirza, Z. The development of MOFs-based nanomaterials in heterogeneous organocatalysis. Sci. Bull. 2018, 63, 502-524. [CrossRef]

8. Valizadeh, B.; Nguyen, T.N.; Stylianou, K.C. Shape engineering of metal-organic frameworks. Polyhedron 2018, 145, 1-15. [CrossRef]

9. Stackhouse, C.A.; Ma, S.Q. Azamacrocyclic-based metal organic frameworks: Design strategies and applications. Polyhedron 2018, 145, 154-165. [CrossRef]

10. Echaide-Gorriz, C.; Clement, C.; Cacho-Bailo, F.; Tellez, C.; Coronas, J. New strategies based on microfluidics for the synthesis of metal-organic frameworks and their membranes. J. Mater. Chem. A 2018, 6, 5485-5506. [CrossRef]

11. Van Vleet, M.J.; Weng, T.T.; Li, X.Y.; Schmidt, J.R. In Situ, Time-Resolved, and Mechanistic Studies of Metal-Organic Framework Nucleation and Growth. Chem. Rev. 2018, 118, 3681-3721. [CrossRef] [PubMed]

12. Furukawa, H.; Cordova, K.E.; O'Keeffe, M.; Yaghi, O.M. The Chemistry and Applications of Metal-Organic Frameworks. Science 2013, 341. [CrossRef] [PubMed]

13. Wu, Y.; Qiu, L.-G.; Wang, W.; Li, Z.-Q.; Xu, T.; Wu, Z.-Y.; Jiang, X. Kinetics of oxidation of hydroquinone to p-benzoquinone catalyzed by microporous metal-organic frameworks $\mathrm{M}_{3}(\mathrm{BTC})_{2}[\mathrm{M}=$ copper(II), cobalt(II), or nickel(II); BTC = benzene-1,3,5-tricarboxylate] using molecular oxygen. Transit. Met. Chem. 2009, 34, 263-268. [CrossRef]

14. Faustini, M.; Kim, J.; Jeong, G.-Y.; Kim, J.Y. Microfluidic Approach toward Continuous and Ultrafast Synthesis of Metal-Organic Framework Crystals and Hetero Structures in Confined Microdroplets. J. Am. Chem. Soc. 2013, 135, 14619-14626. [CrossRef] [PubMed] 
15. Almáši, M.; Zeleňák, V.; Opanasenko, M.; Císařová, I. Ce(III) and Lu(III) metal-organic frameworks with Lewis acid metal sites: Preparation, sorption properties and catalytic activity in Knoevenagel condensation. Catal. Today 2015, 243, 184-194. [CrossRef]

16. Peng, M.M.; Jeon, U.J.; Ganesh, M.; Aziz, A.; Vinodh, R.; Palanichamy, M.; Jang, H.T. Oxidation of Ethylbenzene Using Nickel Oxide Supported Metal Organic Framework Catalyst. Bull. Korean Chem. Soc. 2014, 35, 3213-3218. [CrossRef]

17. Da Luz, L.L.; Viana, B.F.; Oliveira da Silva, G.; Gatto, C.C.; Fontes, A.M. Controlling the energy transfer in lanthanide-organic frameworks for the production of white-light emitting materials. CrystEngCom 2014, 16, 6914-6918. [CrossRef]

18. Kareiva, A.; Karppinen, M.; Niinistö, L. Sol-gel synthesis of superconducting $\mathrm{YBa}_{2} \mathrm{Cu}_{4} \mathrm{O}_{8}$ using acetate and tartrate precursors. J. Mater. Chem. 1994, 4, 1267-1270. [CrossRef]

(c) 2018 by the authors. Licensee MDPI, Basel, Switzerland. This article is an open access article distributed under the terms and conditions of the Creative Commons Attribution (CC BY) license (http://creativecommons.org/licenses/by/4.0/). 